\title{
Religious education as opening the hermeneutical space
}

\author{
Didier Pollefeyt $^{1}$
}

Published online: 10 July 2020

(c) Australian Catholic University 2020

\begin{abstract}
A hermeneutic-communicative model of religious education is proposed which is grounded in a Christian anthropology. The human person is presented as a 'fragile hermeneutical space' - consisting of a radical openness to reality, an essential indeterminateness and an ability to transcend his or her own reality. This means that people have an inbuilt capacity for receiving meaning. One of the tasks of religious education is to allow children and young people to discover this hermeneutical space within themselves and others. The radical openness of the human person to God is discussed, as are the deficiencies of mono-correlational pedagogies in a pluralised context and the importance of teachers having something to say about the Christian tradition and the way they have integrated it in their own lives.
\end{abstract}

Keywords Religious education · Hermeneutical interjunctions · Correlation · Hermeneutical space

\section{The lustre of human life}

In this contribution, I intend to focus on the Christian image of the human person that provides the basis of the hermeneutic-communicative model of Roman Catholic education (Lombaerts and Pollefeyt 2004; Pollefeyt 2020). Roman Catholic religion as a subject is confessional by nature and in orientation: the educator's point of departure is not some neutral anthropology (as if such a stance were possible), but is clearly coloured by a specific anthropology, one derived from the Jewish and Christian traditions (Burggraeve 2019). In the Genesis story we read that human beings are made in the image of God. This is a strange statement, because in the Hebrew bible it is clearly stated that it is forbidden to make images of God (Deut. 5:8). How can God create the human person in His image and likeness, while at the same time we are forbidden to identify and worship images of God? This paradoxical question can only be answered by accepting that there is a reality hidden in human beings that cannot be depicted or defined or placed in human or scientific categories such as we have in biology (my genes), psychology (my character) or sociology (my social position). Put simply, there is more to discern in the human person than is visible.

Didier Pollefeyt

Didier.Pollefeyt@theo.kuleuven.be

1 Faculty of Theology and Religious Studies, KU Leuven, Leuven, Belgium 
The 'lustre' of human beings is always more than their genetic code, the colour of their skin, their gender, character, origins, occupation, social standing, nation, people or religion. A human being by definition escapes being characterised by any of these aspects (traditionally people spoke of human beings as being bearers of a 'soul'). This is something we all experience when we raise children: they always are and will always turn out different from what we try to plan and bring about through our own desires and care. It is something they always manage to escape to some extent (though usually not completely). This, in a positive sense, means that a human being is a 'life-filled 'image of God', is receptive and has the ability to be creative in the development of his or her own life. It means that not everything about being human is or can be predetermined (Chalier 1989). This is at the heart of the Judeo-Christian inspired anthropology that underlies the hermeneutic-communicative model of religious education.

\section{Fragile hermeneutical space}

In this article we identify the nature of the person as a 'fragile hermeneutical space'. The essence of a human being consists of a radical openness to reality, an essential indeterminateness, an ability to transcend his or her own reality. While there are traces of the Divine in animals, for the human person God-self is expressed via the face-as the revelation of a radical otherness, indeterminacy and vulnerability that goes beyond the physical attributes (Levinas 1969). This means that people have an inbuilt capacity for receiving meaning: we can discover the lustre of life; we can ascribe meaning; but we are also capable of recognizing and acknowledging others as 'like me', as individuals in search of, longing for, and absorbing meaning. In the human subject we call this the 'hermeneutical space': a place of openness, freedom, sensitivity, self-transcendence, and of receptivity for otherness and for a rich plurality of implicit and explicit meanings and interpretations. It is also the place where God can reveal God-self as the ultimate, fulfilling other. One of the tasks of religious education is to allow children and young people to discover this hermeneutical space within themselves and others. They can discover this through the highs and lows of life, through beauty and comfort, pain and suffering, symbols, rituals and stories, the mystery and the incomprehensible, the forgiving nature and hard edge of reality, as well as through our frail, vulnerable and excluded fellow human beings and the fragility of nature. The intention of Catholic religion as a subject is to explore this hermeneutical space and open it up more and more in children and young people so that they can read reality with philosophical and religious spectacles and discover that nothing is normal, obvious or simple. This anthropology assumes that every human being, without exception, religious or nonreligious, Christian or otherwise, is characterised by this hermeneutical openness and that, by way of this openness, this indeterminacy, the given of existence, everyone has to sort out his or her own thinking. It assumes that everyone can create, discover and exchange sense, meaning and orientation within this openness. It is through this shared openness that all people are also structurally linked as relational beings. To sum up: one of the principal objectives of Catholic religion as a subject is to awaken hermeneutical reflection in all the students by allowing them to discover this space of self-transcendence, no matter what they do with it in their future lives. Because of this universalism, also the intrinsic and independent value of the pedagogical is recognised because of its relevance for all students and people. 
We call this hermeneutical space fragile because it exposes a fundamental openness to reality, making us particularly vulnerable. These days there are many players in the market for meaning, ideology, religion and politics, all wanting to voice their own interpretation and to shape our hermeneutical space. There is no longer an overarching philosophical or religious system that offers a completely conclusive and satisfying answer to all the questions and possibilities, temptations and threats that crop up within the hermeneutical space. Reality - also our own inner reality - is radically marked by a form of 'polyphony', by a multiplicity of voices, by plurality. The hermeneutical space is thus fragile because it is exposed, even to fundamentalism and relativism. On the one hand, fundamentalism presents the false promise of stability and security, often at the expense of others and oneself. Fundamentalism promises clarity among the voices, but instead conceals multiplicity, otherness and difference as noise, as a threat, thus justifying the radical exclusion of otherness and the closing off of the space for encounter, interpretation and authentic dialogue. On the other hand creeps in relativism and nihilism, which eradicates authentic difference with sameness, containing nothing that is absolute, no longer recognizing anything as sacred. Phenomena such as a complete absence of standards and norms and senseless violence can be extreme manifestations of this. Both fundamentalism and relativism threaten to destroy one's own space and that of others by hollowing out or erasing any and all resources for dialogue among meaningfully unique interlocutors.

Fundamentally, the fragility of the hermeneutical space is constant. Life continuously presents itself in challenging and innovative ways in people's daily experiences of joy and pain. This can sometimes be in the form of real ground-breaking experiences that force young on a serious and complex level-especially the words of one's innermost life. But even in less extreme cases, the hermeneutical space of human beings is vulnerable and also manipulable. Since all of the great stories are today being deconstructed, for example, there is the risk that the strong operating force of the market economy will take root in human desire, quietly manifesting itself as the only valid, meaningful and existing narrative for humanity and society. The entire story of human existence would then be reduced to an endless chain of production and consumption. People respond to the meanings created by the economy which often take over and fill the hermeneutical space with a desire for economic goods and the social status attached therein. Young people often do not realize how this whole process is being driven by the blind law of maximising profit. They lose sight of how this process creates victims, both fellow human beings and within the larger ecological system. The rapid succession of economic crises and the flare-ups of violence in major cities also increasingly expose this ideology as a false bringer of good fortune. The cumulative destruction of nature, the constant vulnerability of the monetary system and the worldwide COVID-19 catastrophe have revealed the limits of this economic model on a world scale.

\section{The saccharine saturation of the hermeneutical space}

One of the well-intentioned but ultimately counterproductive responses that can be made to the fragility of the hermeneutical space is to take an overly-protective approach. Here, the students are only allowed to encounter the positive dimensions of life, with teachers deliberately avoiding those elements that are more challenging and interruptive such as the realities of suffering, sin, evil, doubt or anxiety. In a religious education classroom this one-sided positive approach finds expression in a theological key when God is considered 
in terms of intimacy and closeness with more challenging theologies being excluded, where God is experienced in terms of Otherness and even of Hiddenness and Absence. A balanced approach to religious education does not only include the positive experiences, it also creates room for students to seek God in times and places where things seem desperate and 'godforsaken'. They are given the message that these experiences in life are often the ones where God is revealed. In an Australian context, the recent bushfires provide an opportunity for reflecting on the ways in which God is revealed in environmental degradation and the liminal experiences associated with drought and global warming. The COVID19 pandemic provides another opportunity for students to reflect more deeply on the nature and purpose of human life. Here teachers are able to become guiding companions, walking alongside the students as they consider issues with no easy answers, as they encounter doubts, anxieties and suffering on a serious and complex level—rather than seeing them airbrushed out of the curriculum. The problem with the one-sided positive approach is not only that it presents students with a distorted version of the tradition. Rather, the deficiencies of this one-side positive approach are compounded when students reject the saccharine version of religious faith as being unviable and unreal in the face of a life that is not always sweet, fair and unambiguous.

\section{Revealing plurality critically}

This analysis gives rise to a second important objective for Catholic religion as a subject, namely, to make students aware of the plurality of views of life, philosophies, ideologies and religions that characterize today's reality-both for the individual and the community - and to try to influence our interpretation of reality. An analysis like this can, on the one hand, open many horizons within our own hermeneutical space. But on the other hand, it can also be deconstructive, particularly in the degree in which the ideologies manipulate and close one's own hermeneutical space or that of others and even destroy it. In this sense, religion as a subject also keeps performing a critical role in the classroom, Church and society. It not only confirms the prevailing plurality, but also calls it into question. Religion as a subject must never be relativistic and the religious educator can never be neutral. Not everything is the same. Whoever or whatever threatens one's hermeneutical space, or that of others and of creation, will be questioned by the RE teacher in the name of the image of God in every human being and His trace in Creation. This also means that there is no room for religious indoctrination in the subject of religion, nor for racism or other violations of human rights. Therein lies perhaps one of the biggest challenges of the subject: the historical legacy of the religions themselves, and the fact that their language, their structure and their history (including even child abuse in the context of religious education itself) are often more likely to snap-shut one's hermeneutical space, to surround it with scepticism and to obscure than to open, clarify and liberate it. In this 'fragile' area, in particular, it is a challenge to give the 'lustre' of experiencing and living that occurs in the lives of young people themselves a (re)new(ed) place in the hermeneutic-communicative approach. 


\section{Original sin}

Ultimately, courses on religion need to create a context in which each student is invited to look at life in a personal way. We can call this the third important objective of Roman Catholic religion as a subject. The basic premise is that the hermeneutical space of each person is already filled or occupied in a particular way. No one is neutral. Everyone has already been touched by life. We are all different. We have made choices. We are not completely autonomous creatures. Many choices have already been made for us, even before we were born. This also applies to religious elements that we have integrated or rejected in a certain way. We are always already thrown into life and affected by reality, both in a positive and a negative way. Everyone carries the truth, but no one can claim to have the full truth. No one is without evil. Perhaps the latter is also the true meaning of the theological concept of original sin. Nobody has the perfect answer to every question. No one can escape responsibility for others or take perfect responsibility. No one is totally free or starts with a clean slate. A hermeneutical approach aims to invite students to find their own philosophical assumptions and feelings, to make them aware of complementary and alternative possibilities and to invite them to allow diversity existing within and without to develop into a polyphonic identity that is as integrated as possible, though ongoing in development. The aim of the subject these days is not for all the students to turn into Christians or Catholics. However, it is true that the intention is that the students should be invited to come to self-enlightenment and religious maturity in complete freedom and to teach them to deal with ideological differences and religious diversity in themselves and in society.

\section{Invisible loyalties}

The search for one's own identity or profoundest individuality involves much more thanand even something fundamentally different from-a rational or purely autonomous choice. After all, we cannot choose our identity. Our identity has been largely preformed and involves visible as well as invisible loyalties concerning which we actually have no choice, but which do nevertheless significantly shape us and provide the basis of our identity (Boszormenyi-Nagy 2014). Our identity has been largely coloured by the fears and dreams of our parents, by the structure of our family and the place that we gain in it, by the schools we attended, the friends we have or have not made, the books that we did or did not read, the poetry and the music we have heard, the bad things and suffering that happened to us, the people we met by chance, the cultural environment, traditions, the spirit of the age, and so on. We can to some extent develop an awareness of our situation and of what is subjective, irrational or suprarational in it and we can actively take on, adjust, enrich, intensify or even rationalize or reject our situation in life.

\section{First and second naivety: the role of hermeneutical junctions}

In the course of religion this development of becoming aware of one's faith always takes place in a process of communication. Students bring different world-view perspectives, which they have often assumed from a kind of initially naive position ('first naivety'), into what happens in the classroom. Years ago, in almost all cases, that would have been a 
Catholic perspective but these days, it is no longer a Catholic or Christian perspective per se, not even in Catholic schools. The subject of religion will recognize, give explicit attention and value to these ideological and religious differences. It is precisely in the confrontation with difference that a more conscious choice, a "second naive position", can be developed ('second naivety') (Ricœur 1971; Moyaert 2014). In 'second naivety', one's faith is re-confessed but with greater consciousness and awareness of one's particularity (e.g. "I am a Catholic") and vulnerability (e.g. "I know it is not self-evident to be a Catholic" or "I know others believe in different ways"). This development from first to second naivety happens especially when students in class are confronted with so-called 'hermeneutical junctions' or 'interpretational conflicts' among each other or with the teacher concerning central life issues. 'Hermeneutical junctions' appear in class when students formulate different opinions or views that cannot be harmonized easily and that refer to different presuppositions, loyalties and interpretations especially of religious traditions that are at work-often implicitly-in their individual hermeneutical spaces. Think for example what happens when a teacher initiates issues in the classroom like the death penalty, poverty, ecology or collective sin. It is the teacher's responsibility to moderate these world-view discussions so that the classroom can become itself a hermeneutical space and to offer insights to the students from the Catholic perspective which he or she represents. This is a delicate task, for students also often feel deeply connected, attached and dedicated to certain opinions, values, symbols, traditions, etc. Dialogue around such hermeneutical junction points is different from an intellectual exercise or a choice made from a supermarket of beliefs. It is a matter of discovering our own intertwined-ness with reality and to allow oneself to be touched by new and different viewpoints: intellectual, but often also social, aesthetic and spiritual. In this sense, the subject of religion has an important social role and responsibility. It makes students more competent for living together with difference and makes them sensitive to the dialogue among religions and worldviews. It is therefore important that everyone is allowed to speak from his or her own position and is not forced into a neutral or indifferent position before he or she is allowed to voice something. People only grow in inter-world-view competences when they have also been invited, challenged and valued to speak from their own perspective. People do not learn how to be religiously engaged if they are compelled to put their own view between brackets and have not even explored it - as is the case in so-called multi-religious learning. In a positive sense, this means that the subject of Roman Catholic religion is inter-religious: it makes room for all worldviews and religions as long as they continue to acknowledge the openness and therefore the fundamental freedom of others.

\section{Open for transcendence}

Importantly, what is it that distinguishes the subject Roman Catholic religion from a course on the 'philosophy of life' or 'search for meaning'? As discussed above, the point of departure for the hermeneutic-communicative model itself is already not neutral but has been coloured theologically by the Jewish and Christian traditions. The principle that man is marked by the ability to transcend himself and to make, create and receive meaning is already coloured confessionally. One might also assume that the search for meaning itself is meaningless and that man is ultimately only a sophisticated chimpanzee that can be completely explained by the theory of evolution or by infra-human processes from biology, psychology and sociology. In that case 'truth', for example, becomes a pragmatic notion; 
'goodness' a regulating principle; 'beauty' a subjective feeling. In addition, those with no faith or a different faith also have very authentic experiences of truth, goodness and beauty and they too can experience the self-transcending wealth of the hermeneutical space.

The hermeneutic-communicative model for the subject of Roman Catholic religion assumes that the hermeneutical space of the human being is not just open to the 'immanent transcendence', to experiences of truth, goodness and beauty in the here-and-now, but is also characterized by a much more radical openness, particularly, an openness to the 'transcendent transcendence': God. Ultimately, it is this connection to the Transcendent that colours and directs everything. Those responsible for the course in Catholic religious education in the Church and very often the young people themselves expect the Roman Catholic religion teacher to live steeped in this Transcendence. Teachers in Catholic religion bear witness to this transcendent God. At the same time, it is important to underline that this transcendence in the Christian tradition is also marked by immanence through the confession of a God who in history was incarnated in a unique way as Jesus of Nazareth, who is Christ (see below).

In light of this analysis, the relationship with God could be described as a break-through into the hermeneutical space of something (or better, Someone) radically different-one that connects, fills, anchors and unifies that which I cannot connect, fill, anchor and unify through my own efforts, but for which I still have a deep longing. For a believer, to experience and meet God is like bathing in a light that comes from elsewhere, that creates unity and tenderness in the hermeneutical space, makes one feel gratitude, brings peace, invites for prayer, promises a future, but also instils a sense of responsibility and allows the world to be seen through different eyes. It is the responsibility of the teacher of religion to show and create understanding of how people of faith can experience the hermeneutical space in this God-fulfilling way and allow it to come into full bloom in words, stories, prayers and rituals, and at least ensure that this possibility is not blocked beforehand-even though it is often the case that religion and religious language can themselves be obstacles to such a transcendent experience in the hermeneutical space. I agree with the Flemish philosopher Guido Vanheeswijck's analysis that nowadays there is often a taboo on this very Transcendence (Van Heeswijck 2019). The confession of the God of Abraham, Isaac and Jacob, the God of Jesus Christ is the confession of faith that the religion teacher will need to present herself in the classroom as a witness.

\section{Monocorrelation}

Regarding this point I would also like to formulate a reflection in connection with the concept of 'Mystagogical-communicative' religious education (Roebben 2009) that is sometimes put forward as an alternative to the 'hermeneutic-communicative' model. 'Mystagogical' religious education is spontaneously understood to mean the furthering of the handling of the mystery of human existence, and in doing so, the mystery of God. As such, this term is not used correctly from a historical point of view. After all, in the Old Church 'mystagogy' was the most advanced form of catechesis for the most highly initiated. In the early Church, mystagogy was the catechesis that was given to those who were recently baptized. The term 'Mystagogical-communicative' suggests that some sort of continuity exists between immersing oneself in the mystery of reality hence perhaps 'mystagogy' and finding the God of the Christian tradition. God does not just reveal Himself in the depth and mystery of one's own hermeneutical space but comes to meet us from elsewhere. In order 
to be able to experience and meet God one must first be initiated in a specific, basic set of stories, symbols, rituals, traditions, etc. that provide the means for the meeting with God in the hermeneutical space. 'Philosophical education' or broader: 'teaching on the meaning or mystery of life' and 'religious education' can therefore not be regarded as the same, and the one does not automatically give rise to the other. In other publications (Pollefeyt and Richards 2019), I have criticized a didactic of 'mono-correlation': the unilateral connection between human experience of depth and religious experiences. Justified criticism that religious education is often no longer religious education is, in my view, due precisely to evident efforts to regard 'religion' and 'philosophy of life' as the same thing; or to too easily make connections between meaning, mystery and God. The assumption here is that if one were only to reflect on life 'deeply enough', God will be found. However, there is no continuous, straight or uninterrupted line between opening the hermeneutical space and the inspiration of Christian faith; between a philosophy of life and religion; between mystery and mystagogy. It is therefore important that we are initiated first before we can become profoundly Christian, just as in the Christian tradition of old when, after the evangelization, initiation catechesis laid the foundation upon which, only much later and after receiving the sacraments, Mystagogical catechesis was offered. Such a Mystagogical approach to religious education, as was well understood in history, is indeed rather ambitious for religious education these days, and there is a risk that use of this term could once again lead to confusion between religious education (compulsory for all) and catechesis (voluntary, for those who have already turned to Christ).

In other words, the experience of God is a very special way of dealing with the hermeneutical space. This transcendent God is not directly available 'just like that' through the experience of the mystery of life. He is therefore a very 'fragile God'. He comes to us through a series of mediations provided to us through stories, rituals, tradition, community, etc. In Christianity, God cannot be encountered without mediation through the Bible, the Tradition and the Church. If these means are not provided, the hermeneutical space cannot become transparent and be a medium for meeting the biblical God. This implies that at a time when Christianity, as a cultural and existential reality, has become less and less a part of a fixture on the horizon of Western culture, the contents of the Christian tradition must be made available more and more explicitly in religious education—but in such a way that its presentation is relevant and plausible for people today.

Christians are convinced that it is precisely the revelation of God in Christ that offers a unique, irreplaceable, non-interchangeable, authentic and life-giving experience of the hermeneutical space in all dimensions of existence, not only for the individual but also for society. Christ is therefore the being whose existence has become the most transparent for encountering God because He comes from God, He is Himself the Son of God. This forms also the core of the class of Roman Catholic religion. Christianity revolves around Christ and His fragile love that lights our way, even to the cross and resurrection. Roman Catholic religion as a subject is only 'Roman Catholic' if and in so far as the Catholic tradition is offered and presented as a living tradition and as a celebrating community that facilitates the relationship with God within the hermeneutical space in a very particular way. Liturgy is in this context also a very strong hermeneutical space where through the power of the sacraments God becomes 'really' present in our midst. 


\section{Deductive component of Catholic religious education}

That brings me to the fourth major objective of Roman Catholic religion as a subject, after 1. Opening the hermeneutical space; 2 . Understanding the plurality at work in it; and 3. Becoming aware of the presuppositions at work in one's own hermeneutical space. It is to offer the wealth of the Christian tradition as a particular mediation structure of the relationship with God in the hermeneutical space. This is the deductive component of Catholic religious education. It is no longer possible to presume the presence of the tradition in the hermeneutical space of all students and to mobilize the tradition in them through a purely inductive approach that starts from the experience. Perhaps the time has come to push this fourth objective more explicitly to the fore, particularly in the professional training of expert teachers of religion. Religious educators must have something to say about the Christian tradition and the way they have integrated it in their own lives and in that of the community. For students who are believers, this approach can have a Mystagogical meaning in the true sense of the word, namely a further initiation into and deepening of religious faith. For some students this can be a first or renewed acquaintance with the Christian tradition.

\section{Truth that enlightens all men}

The hermeneutic-communicative model also accepts and appreciates that in the case of some students the hermeneutical space is structured or oriented from a different philosophical or religious tradition, such as Islam or secular humanism. From these traditions, likewise, students can also speak and live authentically, even though they do not explicitly experience the God experienced by Christians as a guiding, life-giving and redemptive God. The Catholic anthropology should be able to accept and confirm that original sin has not completely destroyed or obscured the hermeneutical space of human beings, but that everyone is able to live morally and even in a religiously authentic way. For this reason, the Church confirmed in the Second Vatican Council that it rejects nothing of what is true and holy in the various religions. "She regards with sincere reverence those ways of conduct and of life, those precepts and teachings which, though differing in many aspects from the ones she holds and sets forth, nonetheless often reflect a ray of that Truth which enlightens all men" (NA 2). If religion as a subject invites and supports those with a different faith to become better Muslims or better humanists, the objective of the course has also been achieved for them.

\section{Pedagogical, social and ecclesial plausibility}

The hermeneutical-communicative model provides a framework that is able, in this day and age, to meet the variety of expectations from Church and society and is also able to create real added value for the individual and for society: 1 . To make students more sensitive with regard to questions of meaning; 2 . To respect the plurality among the students to the very end; 3. To invite and support students to self-understanding; and 4. To present the wealth of the Christian tradition in a witnessing and expert way as something that drives all the 
objectives of the class of Catholic religious education. That is a service to young people, the Church and society. For some the course will give too much or too little attention to the plurality, for others too much or too little deference to the Christian tradition or too much or too little opportunity for reflection on the growth of one's own worldview. The core of the subject, however, consists of engaging with the pluralistic context and the Christian tradition by means of the ears and the mouths of the students themselves. It is precisely that dialogue which, if obstructed, will leave the classroom either: 1. Utterly pluralistic, incapable of doing justice to the internal dynamics of the belief stances themselves; or 2. With a catechesis that cannot possibly be made compulsory for everyone in schools that are open for all; or, finally, 3. A subject that involves navel-gazing among a student body empowered only to tolerate experiences and perspectives that are (the same as) their own.

\section{References}

Boszormenyi-Nagy, I. (2014). Invisible loyalties. Milton Park, Oxfordshire: Taylor \& Francis Ltd.

Burggraeve, R. (2019). "When in the 'Brother' the Stranger is Acknowledged": From identity to alterity and dialogue, according to Emmanuel Levinas. Journal of Dharma, 43(3), 285-310.

Chalier, C. (1989). L'Alliance avec la nature. Paris: Cerf.

Levinas, E. (1969). Totality and infinity, an essay on exteriority. Translated by Alphonso Lingis. 25th printing, 2013 ed. Duquesne University Press: Pittsburg.

Lombaerts, H., \& Pollefeyt, D. (Eds.). (2004). Hermeneutics and religious education. Leuven: Peeters.

Moyaert, M. (2014). Response to the religious other: Ricœurs and the fragility of interreligious encounters. Lanham: Lexington.

Pollefeyt, D. (2020). Hermeneutical learning in religious education. Journal of Religious Education, 68, $1-10$.

Pollefeyt, D., \& Richards, M. (2019). The living art of religious education: A paradigm of hermeneutics and dialogue for RE at faith schools today. British Journal of Religious Education, 41, 1-12.

Ricœur, P. (1971). La foi soupçonnée. Foi et religion. Recherches et débats. Seminaire des intellectuels catholiques, 73, 64-75.

Roebben, B. (2009). Seeking sense in the city: European perspectives on religious education (p. 118). Münster, Germany: LIT-Verlag.

Sharkey, P. (2015). Educator's guide to catholic identity. Mulgrave: Vaughan Publishing.

Van Heeswijck, G. (2019). The Place of religion in the secular society. In J. Creemers (Ed.), Religion and state in secular Europe today: Theoretical perspectives and case studies (pp. 15-34). Leuven: Peeters.

Publisher's Note Springer Nature remains neutral with regard to jurisdictional claims in published maps and institutional affiliations. 